\title{
ROOT COLONIZATION AND INTERACTION AMONG GROWTH PROMOTING RHIZOBACTERIA ISOLATES AND EUCALYPTS SPECIES ${ }^{1}$
}

\author{
Reginaldo Gonçalves Mafia ${ }^{2}$, Acelino Couto Alfenas ${ }^{3}$, Eraclides Maria Ferreira ${ }^{3}$, Daniel Henrique Breda \\ Binoti $^{3}$, Gizella Machado Ventura Mafia ${ }^{4}$ e Ann Honor Mounteer ${ }^{5}$
}

\begin{abstract}
This work aimed to evaluate root colonization and interaction among isolates of rhizobacteria and eucalypt species. The method used to evaluate "in vitro" root colonization was able to indicate if the effect was benefic or deleterious allowing to pre-select isolates as potential growth promoter. There was interaction among isolates of rhizobacteria and Eucalyptus species for seed germinating and seedling growth. MF2 (Pseudomonas sp.) was the best rhizobacteria isolate for growth promotion of E. cloeziana e E. grandis. S1 (Bacillus subtilis) was the most effective for E. globulus, and Ca (Pseudomonas fulva), MF2 (Pseudomonas sp.), CIlb (Stenotrophomonas maltophilia) and S2 (B. subtilis) were the most promising isolates for the E. urophylla.
\end{abstract}

Key words: Eucalyptus, root colonization, rhizosphere.

\section{COLONIZAÇÃO DE RAÍZES E INTERAÇÃO ENTRE ISOLADOS DE RIZOBACTÉRIAS PROMOTORAS DO CRESCIMENTO DE PLANTAS E ESPÉCIES DE EUCALIPTO}

\begin{abstract}
RESUMO - O presente trabalho teve como objetivos avaliar a colonização de raízes e a interação entre isolados de rizobactérias e espécies de eucalipto. O método de avaliação da colonização de raízes "in vitro" possibilitou determinar o efeito benéfico ou deletério, permitindo uma pré-seleção de isolados potencialmente promotores de crescimento. Constatou-se interação entre isolados de rizobactérias e espécies de Eucalyptus em relação à germinação de sementes e o crescimento de mudas. MF2 (Pseudomonas sp.) foi o melhor isolado de rizobactéria para promoção de crescimento de E. cloeziana e E. grandis. Para E. globulus, destacou-se o S1 (Bacillus subtilis). Para E. urophylla, os isolados mais promissores foram Ca (Pseudomonas fulva), MF2 (Pseudomonas sp.), CIIb (Stenotrophomonas maltophilia) e S2 (B. subtilis).
\end{abstract}

Palavras chave: Eucalyptus, colonização de raízes, rizosfera.

\section{INTRODUCTION}

Bacteria are commonly found organized in microcolonies in the rhizosphere. At the same time that these micro-colonies benefit from the nutrients secreted by plant root systems they can also directly or indirectly stimulate plant growth. These growth promoting rhizobacteria are classified as biofertilizers, plant stimulators or biological control agents, according to the degree to which they can fix nitrogen, directly promote growth or protect plants against plant pathogens, respectively (BLOEMBERG e LUGTENBERG, 2001).

\footnotetext{
${ }^{1}$ Recebido em 25.09.2007 e aceito para publicação em 26.01.2009.

${ }^{2}$ Aracruz Celulose S.A. Centro de Pesquisa e Tecnologia. E-mail: <rgoncalves@ aracruz.com.br>.

${ }^{3}$ Departamento de Fitopatologia da Universidade Federal de Viçosa (UFV). E-mail: <aalfenas@ ufv.br>, <ferreiraem@yahoo.com.br>, <danielbinoti@yahoo.com.br>

${ }^{4}$ Departamento de Fitotecnia da UFV.

${ }^{5}$ Departamento de Engenharia Civil da UFV. E-mail: <ann@ufv.br>.
} 
Mechanisms involved in rhizobacterial induced growth promotion are not totally elucidated but are known to include the ability to produce or alter the concentration of plant hormones such as indole-3-acetic acid (IAA), gibberellic acid, cytokynins and ethylene; to asymbiotically fix nitrogen; and to act as antagonists against microbial plant pathogens either through production of siderophores, $\beta$-1,3-glucanase, chitanase, antibiotics and cyanide or through solubilization of mineral phosphate and other nutrients (CATTELAN et al., 1999; CUNHA et al., 2006).

Use of plant growth promoting rhizobacteria (PGPR) appears to favor seedling production, mainly through direct growth promotion and disease control. The term PGPR was used to describe asymbiotic soil bacterial isolates with the ability to colonize plant roots and stimulate their growth, belonging mainly to the genera Pseudomonas and Bacillus. Other PGPR genera include: Azotobacter, Arthrobacter, Clostridium, Hydrogenophaga, Enterobacter, Serratia and Azospirillum (BENIZRI et al., 2001). Rhizobacterial isolates that promote seed germination have been designated as emergence promoting rhizobacteria (EPR) (CHANWAY, 1997).

The use of rhizobacteria is a promising technology for tree species and has been shown to increase plant dry weight from 15 to $30 \%$ and even up to $100 \%$ in special cases (CHANWAY, 1997; TEIXEIRA et al., 2005). Several studies have been performed on gymnosperms with most focusing on conifers of the genera Pinus, Picea, Tsuga and Pseudotsuga (CHANWAY e HOLL 1993a,b; 1994; CHANWAY, 1997; SHISHIDO e CHANWAY, 2000). Application of Agrobacterium spp. in Pinus sylvestris L. led to a $15 \%$ increase in dry weight of seedlings grown. Isolates of Arthrobacter citreus and Pseudomonas fluorescens promoted significant increases in shoot height and dry weight in Picea mariana (Miller) Britton, Sterns \& Poggenburg and Picea glauca (Moench) Voss. Inoculation of Pseudotsuga menziesii (Mirbel) Franco seedlings with unidentified rhizobacterial isolates produced concomitant increases in plant height and diameter of up to $27 \%$. Finally, Tsuga heterophylla (Rafinesque) Sargent seedlings inoculated with Bacillus polymyxa presented dry weight gains of over $30 \%$ (CHANWAY, 1997). The efficiency of rhizobacterial isolates in inducing rooting of Eucalyptus cuttings and mini-cuttings and promoting seedling growth was recently demonstrated. Gains varied according to the rhizobacterial isolate and eucalypt clone, but reached double the average rooting efficiency and triple the root dry weight (TEIXEIRA et al., 2005; MAFIA et al., 2005).

The ability to colonize plant root systems is an important criterion for selecting rhizobacterial isolates for plant growth promotion. However, the methods used to evaluate colonization are complex and costly (SILVA et al., 2003) and the magnitude of the effect in different plant genotypes varies with the rhizobacterium used (CHANWAY et al., 1991b).

In this study, we evaluated efficiency of root colonization and the differential growth responses of Eucalyptus seedlings propagated from seeds inoculated with rhizobacteria.

\section{MATERIALS AND METHODS}

\section{Rhizobacteria isolation}

Isolation of rhizobacteria was performed using 35 to 60 days old eucalypt seedlings from different regions of Brazil, as previously described (TEIXEIRA et al., 2005).

\section{Root colonization}

Eucalyptus grandis Hill ex Maiden seeds were surface disinfected by immersion in ethanol $(50 \% \mathrm{v} /$ v) for $30 \mathrm{~s}$, followed by sodium hypochlorite $(5 \% \mathrm{v} /$ v) for $1 \mathrm{~min}$, washed three times with sterile water and then microbiolized in suspensions of the rhizobacterial isolates at $10^{8} \mathrm{cfu} / \mathrm{mL}$ (concentration was adjusted, in a spectrophotometer, to $\mathrm{OD}_{540}=0.2$ ) at room temperature $\left(27 \pm 2^{\circ} \mathrm{C}\right)$ for $24 \mathrm{~h}$. Microbiolized seeds were aseptically transferred to test tubes containing $0.4 \%$ agar-water and maintained in a growth chamber at $26^{\circ} \mathrm{C}, 12 \mathrm{~h}$ photoperiod and $40 \mu \mathrm{mol} . \mathrm{s}^{-1} \cdot \mathrm{m}^{-2}$ light intensity, for 60 days. Root colonization was observed visually as a turbid zone around the roots. To confirm colonization, roots were transferred to Petri dishes containing Kado \& Heskett medium (KADO e HESKETT, 1970) and incubated at $28^{\circ} \mathrm{C}$ in the dark. Each isolate was classified as beneficial or harmful by comparing plants originating from microbiolized seeds to those originating from sterile seeds (control).

\section{Inoculum preparation}

Nine isolates were tested in Eucalyptus globulus Labill and E. cloeziana F. Muell and seven isolates were tested in the remaining species. The isolates used (Table 1) were previously selected according to their capacity to promote root and shoot dry weight gains 
and to induce adventitious root production in eucalypt clone cuttings and mini-cuttings (TEIXEIRA et al., 2005).

Each isolate was grown separately in Kado \& Heskett medium for $48 \mathrm{~h}$ in the dark. After incubation the bacterial biomass was transferred to sterile saline solution $(0.85 \%$ $\mathrm{NaCl})$. The inoculum concentration was adjusted an $\mathrm{OD}_{540}$ of 0.2 , corresponding to approximately $10^{8} \mathrm{cfu} /$ $\mathrm{mL}$. The inoculum suspensions were stored at $10^{\circ} \mathrm{C}$ for a maximum of $24 \mathrm{~h}$ before use.

\section{Germination of microbiolized seeds}

To verify the effects of rhizobacterial isolates on Eucalyptus spp. seed germination, disinfected seeds as described previously were immersed in inoculum suspension $\left(10^{8} \mathrm{cfu} / \mathrm{mL}\right)$ of the different isolates for $24 \mathrm{~h}$ at room temperature. After drying for 60 minutes in a laminar flow hood, 30 seeds of each species were sown in gerbox-type plastic boxes $(13 \times 13 \times 4 \mathrm{~cm})$, containing $100 \mathrm{~g}$ of partially decomposed pine bark substrate (Plantmax $\left.{ }^{\circledR}, \mathrm{PR}, \mathrm{Brazil}\right)$ and incubated at 27 ${ }^{\circ} \mathrm{C}$, with a $12 \mathrm{~h}$ photoperiod at a light intensity of 40 $\mu \mathrm{mol} . \mathrm{s}^{-1} \cdot \mathrm{m}^{-2}$. The number of germinated seeds was daily evaluated from the third day after the start of the experiment until germination stabilized.

\section{Growth promotion}

The inoculum suspension of each isolate was mixed with substrate $\left(\operatorname{Plantmax}{ }^{\circledR}\right)$ at $0.1 \mathrm{~mL}$ inoculum per cubic centimeter of substrate. The well-mixed inoculated substrate was added to plastic containers $(50 \mathrm{~mL})$ to which seeds of E. cloeziana, E. globulus, E. grandis and
E. urophylla were added and covered with a two cm thick layer of fine-grained vermiculite. Plant height and root and shoot dry weights were quantified after 90 days.

Plant growth was determined using plant height and root and shoot dry weights. Plant height was measured as the distance from the last leaf bud to the soil surface. Dry weight was determined by removing the seedlings from the plastic containers, washing off adhered substrate under running water, separating the shoot from the roots and drying both parts at $70^{\circ} \mathrm{C}$ for $48 \mathrm{~h}$.

\section{Statistical analyses}

A random experimental design was used for each species, with five replicates for isolate. Each replicate contained 30 seeds per gerbox boxes in the assay on the effect of rhizobacteria on seed germination, while each replicate contained 50 seedlings for the experiment on growth effects. Analysis of variance (ANOVA) was performed and means were compared by the Duncan test at 5\% probability level using the SAS (V. 8) software package (SAS Institute, Cary, NC, USA).

\section{RESULTS AND DISCUSSION}

Colonization was visually observed for $16(32 \%)$ of the fifty isolates tested, while colonization was confirmed for another 14 (28\%) of the isolates only after transferring root segments to culture medium. Of the root colonizing isolates, $21(70 \%)$ were beneficial while $9(30 \%)$ were deleterious to the seedlings, causing root necrosis and plantlet death (Figure 1).

Table 1 - Identification of isolates used in this study and eucalypt species tested Tabela 1 - Identificação dos isolados utilizados no estudo e espécies de eucalipto testadas

\begin{tabular}{|c|c|c|}
\hline Isolate & Identification & Eucalypt species \\
\hline \multirow[t]{4}{*}{3918} & Bacillus subtilis Cohn, 1872 / & \multirow{4}{*}{$\begin{array}{l}\text { Eucalyptus cloeziana (EC) } \\
\text { Eucalyptus grandis (EG) } \\
\text { Eucalyptus globulus (EGL) } \\
\text { Eucalyptus urophylla (EU) }\end{array}$} \\
\hline & B. vallismortis Roberts et al., 1996 & \\
\hline & 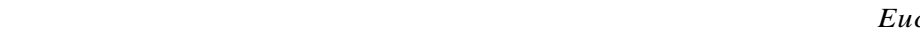 & \\
\hline & & \\
\hline FL2 & Pseudomonas sp. Migula, 1894 & $\begin{array}{c}\text { Eucalyptus urophylla (EU) } \\
\text { EG/EU }\end{array}$ \\
\hline $\mathrm{S} 2$ & Bacillus subtilis Cohn, 1872 / B. vallismortis Roberts et al., 1996 & $\mathrm{EC} / \mathrm{EG} / \mathrm{EGL} / \mathrm{EU}$ \\
\hline S1 & Bacillus subtilis Cohn, 1872 / B. vallismortis Roberts et al., 1996 & $\mathrm{EC} / \mathrm{EG} / \mathrm{EGL} / \mathrm{EU}$ \\
\hline MF2 & Pseudomonas sp. Migula, 1894 & EC/EG/EGL/EU \\
\hline MF4 & Pseudomonas sp. Migula, 1894 & EC/EGL \\
\hline \multirow[t]{3}{*}{$\mathrm{CIIb}$} & Stenotrophomonas maltophilia (Hugh, 1872) & \multirow[t]{3}{*}{ EC/EG/EGL/EU } \\
\hline & Palleroni \& Bradbury, 1993 / & \\
\hline & S. nitritireducens Finkmann et al., 2000 & \\
\hline $\mathrm{Ca}$ & Pseudomonas fulva Lizuga \& Komagata, 1963 & $\mathrm{EC} / \mathrm{EG} / \mathrm{EGL} / \mathrm{EU}$ \\
\hline $\mathrm{R} 1$ & Frateuria aurantia Swings et al., 1980 & EC/EU \\
\hline $\mathrm{VC} 2$ & Not identified & $\mathrm{EC} / \mathrm{EGL}$ \\
\hline
\end{tabular}



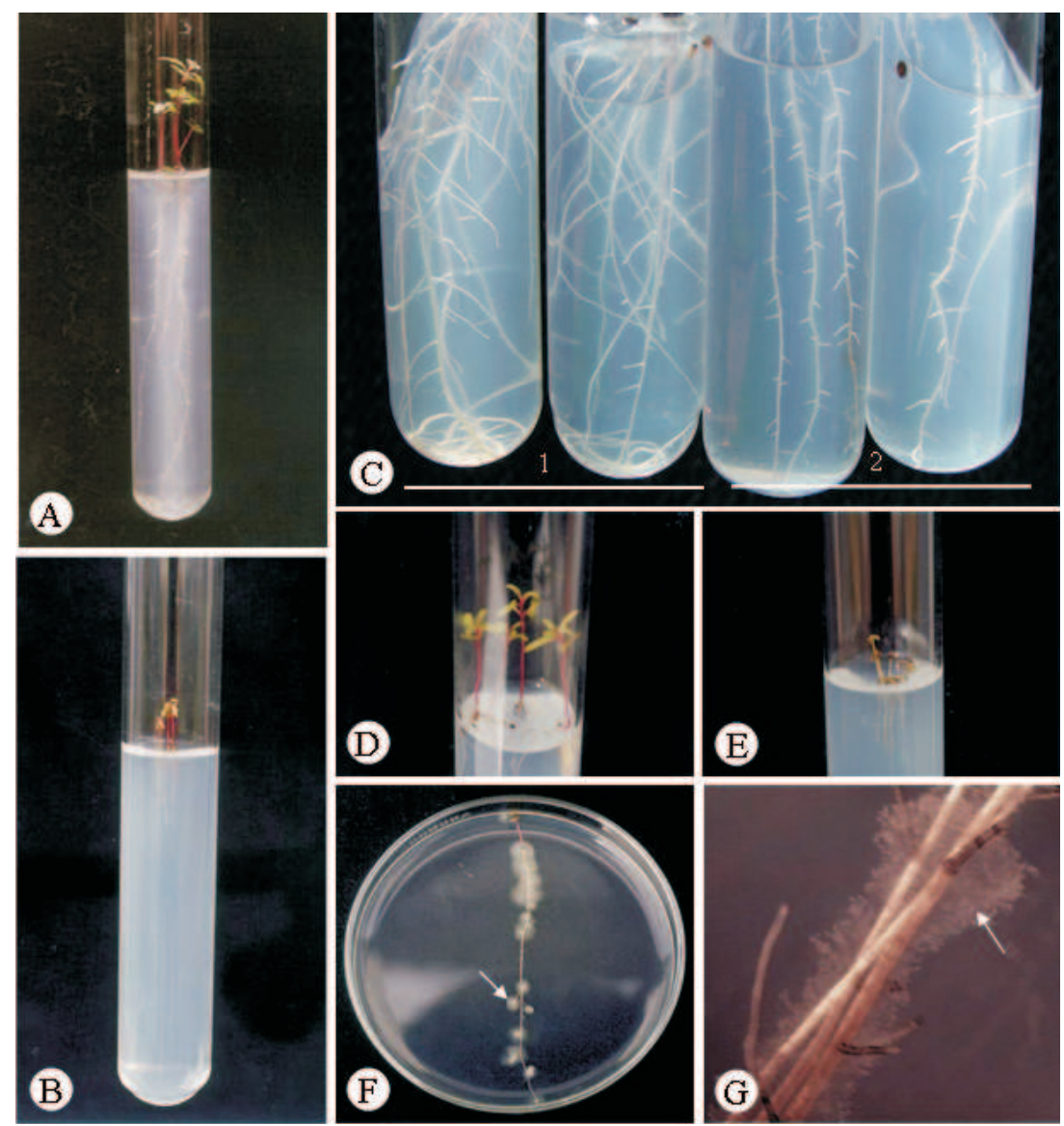

Figure 1 - Effect of in vitro microbiolization of eucalypt seeds by rhizobacterial isolates and confirmation of colonization: A - Normal root and shoot development; B - Plant death caused by rhizobacterial root colonization; C - Visual differences in root volumes of seedlings grown from (1) microbiolized and (2) non-microbiolized seeds; D and E - Visual difference in shoot development in a seedling microbiolized with (D) a beneficial isolate and (E) a harmful isolate; F - Confirmation of colonization (arrow) of roots in agar-water; and G - Detail of the turbid zone (arrow) around the root system.

Figura 1 - Efeito "in vitro" da microbiolização de sementes de eucalipto por rizobactérias e confirmação da colonização: $A$ - Desenvolvimento normal de raízes e da parte aérea; $B$ - Morte de planta causada por colonização radicular de rizobactéria; $C$-; $D$ e $E$-Diferença visual na parte aérea de mudas a partir de sementes microbiolizadas com isolado benéfico $(D)$ e deletério $(E) ; F$ - Confirmação da colonização (setas) de raízes em ágar água; $e \quad G$-Detalhes da zona de turbidez (seta) ao redor do sistema radicular.

The effect of rhizobacteria varied with the Eucalyptus species tested. In E. cloeziana, isolate MF2 promoted a $24 \%$ increase in height. The remaining isolates did not induce or decreased plant growth (Figures 2 A-D).

E. grandis responded positively all to isolates on height and shoot dry weight (Figures 2 E-H). With the exception of FL2 and MF2, all isolates promoted significant increases in seed germination, especially Ca that produced a $462 \%$ increase in relation to the control. Isolate MF2 promoted a $75 \%$ increase in height and a $148 \%$ increase in shoot dry weight over the control.

Isolate S1 was most effective for E. globulus, promoting significant increases in seed germination (79\%), height (33\%) and root $(92 \%)$ and shoot $(79 \%)$ dry weights. Isolate $\mathrm{Ca}$ increased seed germination and root dry weight while isolate MF4 significantly increased plant height and shoot dry weight. The remaining isolates did not significantly affect plant growth (Figures $3 \mathrm{~A}-\mathrm{D})$. 
A

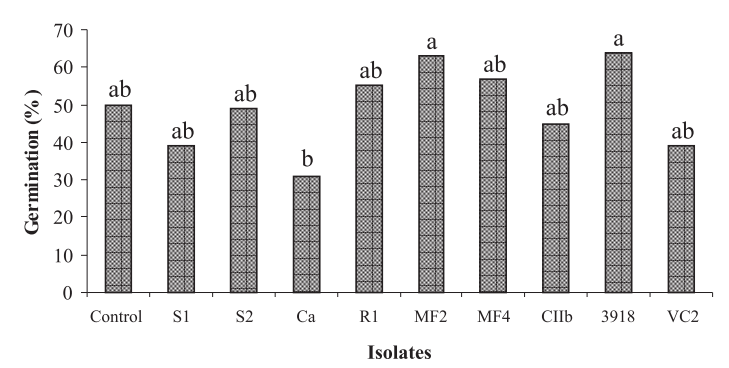

$\mathrm{C}$

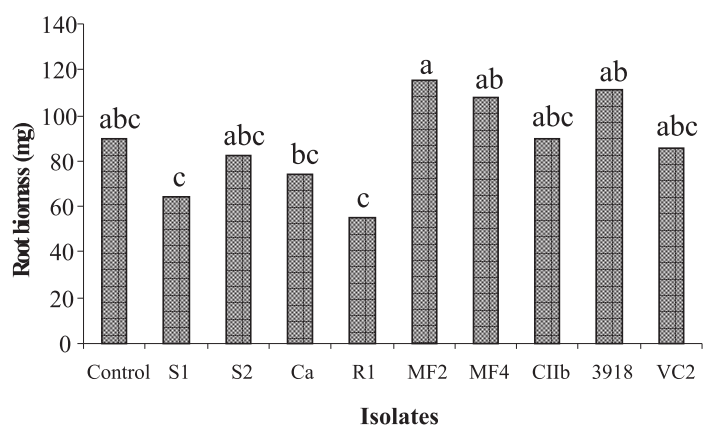

$\mathrm{E}$

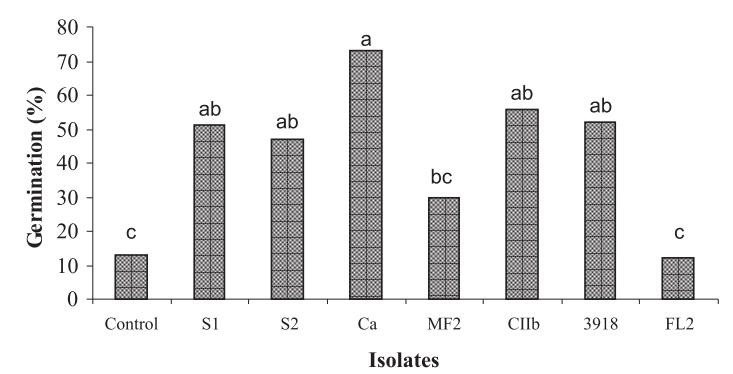

G

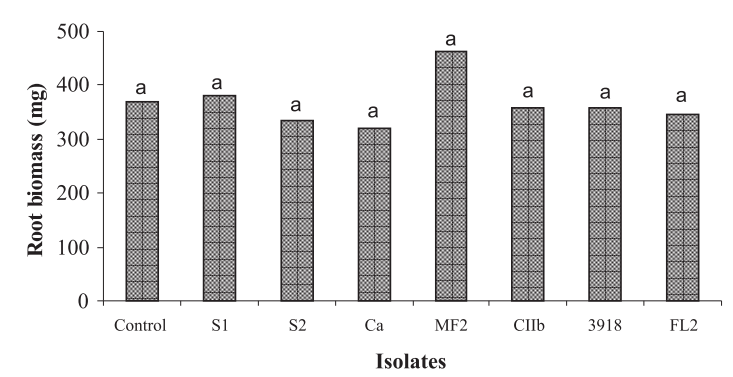

B

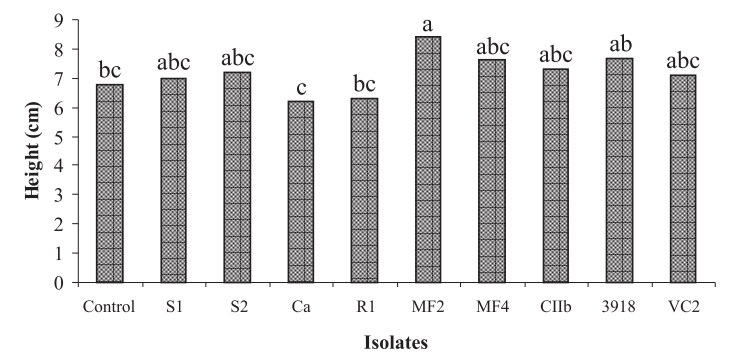

$\mathrm{D}$

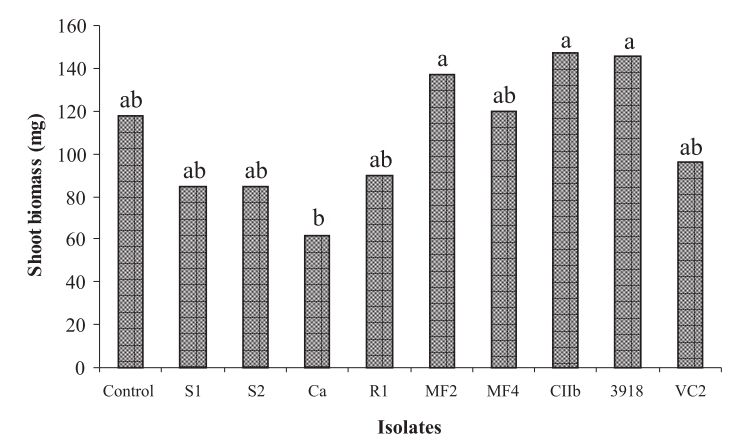

$\mathrm{F}$

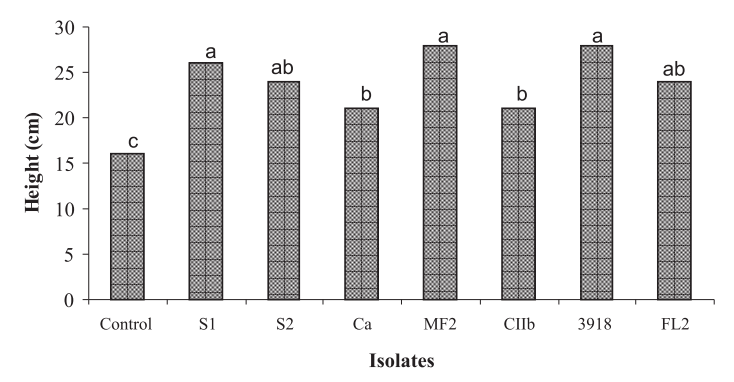

$\mathrm{H}$

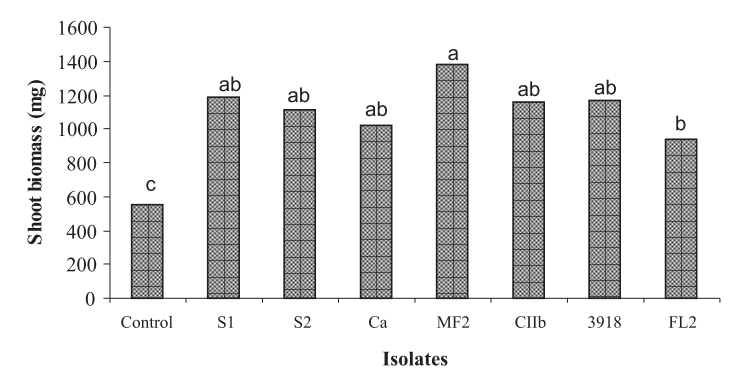

Figure 2 - Germination and growth of Eucalyptus cloeziana (A-D) and Eucalyptus grandis (E-H) from seeds microbiolized with rhizobacteria. Bars under the same letter do not differ statistically (Duncan test, $\mathrm{p}<0.05$ ).

Figura 2 - Germinação e crescimento de Eucalyptus cloeziana (A-D) e Eucalyptus grandis $($ E-H) a partir de sementes microbiolizadas com rizobactérias. Barras sob a mesma letra não diferem estatisticamente (teste de Duncan, $p<0,05$ ). 
A

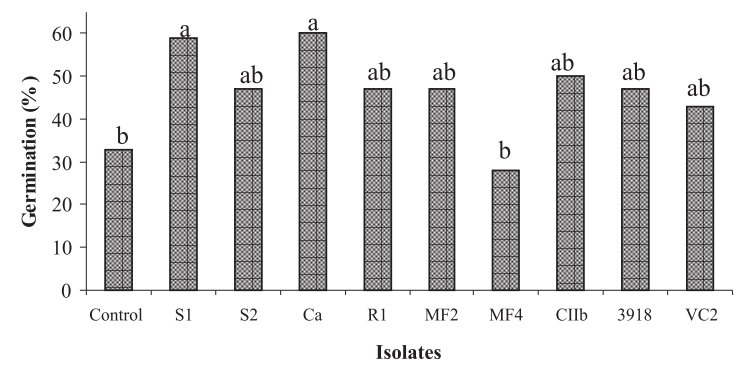

C

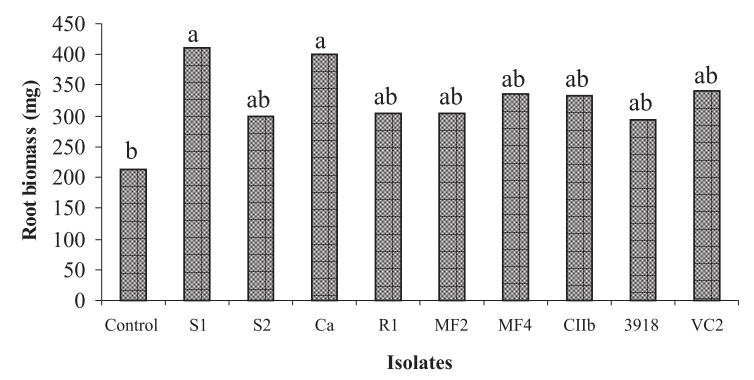

E

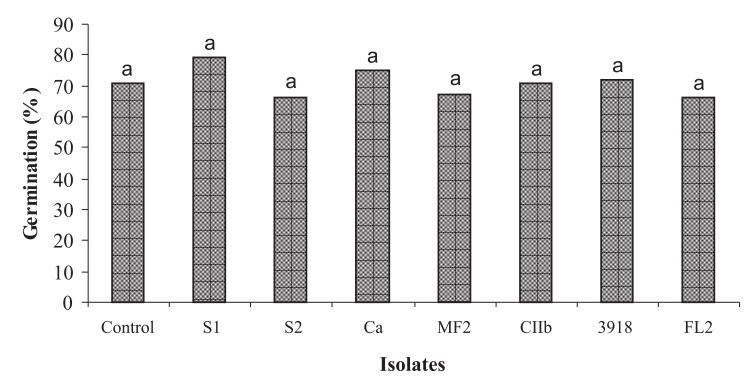

$\mathrm{G}$

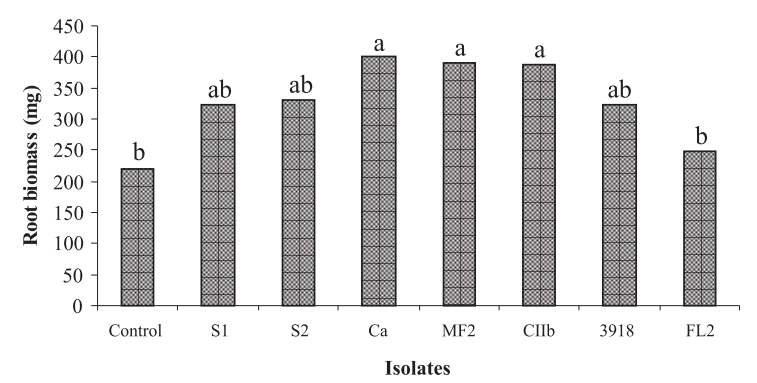

B

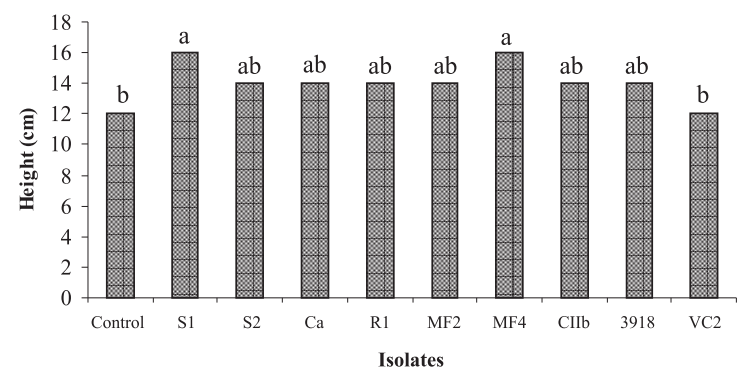

D

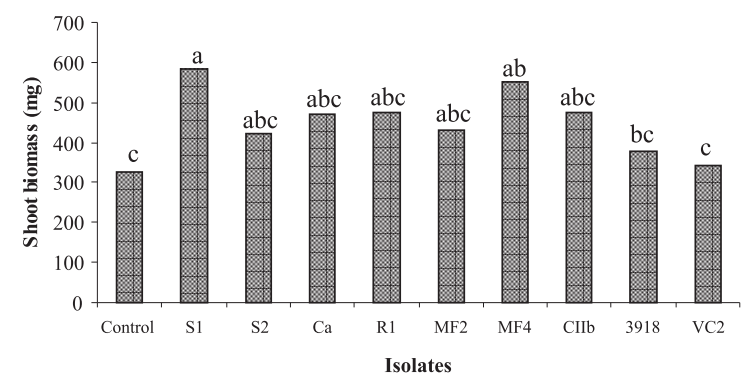

F

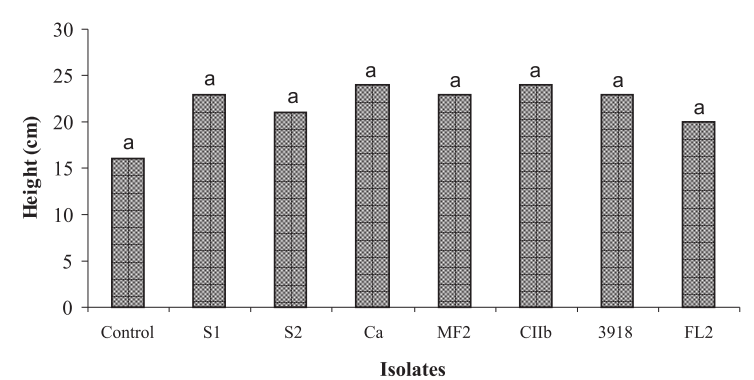

$\mathrm{H}$

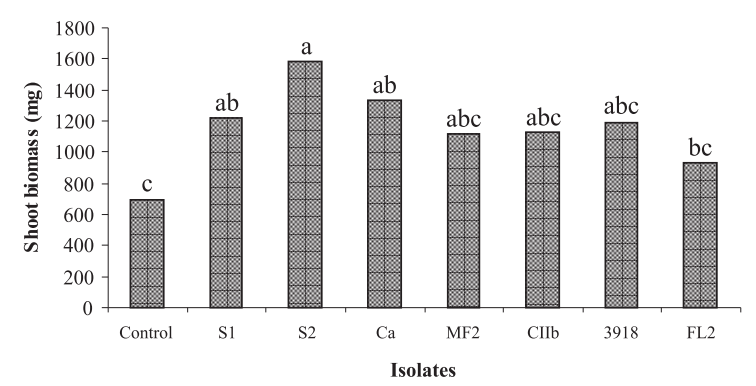

Figure 3 - Germination and growth of Eucalyptus globulus (A-D) and Eucalyptus urophylla (E-H) from seeds microbiolized with rhizobacteria. Bars under the same letter do not differ statistically (Duncan test, $\mathrm{p}<0.05$ ).

Figura 3 - Germinação e crescimento de Eucalyptus globulus $(A-D)$ e Eucalyptus urophylla $(E-H)$ a partir de sementes microbiolizadas com rizobactérias. Barras sob a mesma letra não diferem estatisticamente (teste de Duncan, $p<0,05)$.

R. Árvore, Viçosa-MG, v.33, n.1, p.1-9, 2009 
Significant increases in E. urophylla root and shoot dry weights were observed, with isolates $\mathrm{Ca}, \mathrm{MF} 2$, $\mathrm{CIIb}$ and $\mathrm{S} 2$ producing the greatest effects. The first three isolates promoted increases that varied from 78 to $83 \%$ in root dry weight. Isolate $\mathrm{S} 2$ increased shoot dry weight by $130 \%$, while isolates $\mathrm{S} 1$ and Ca presented dry weight gains of 77 and $94 \%$ over the control, respectively (Figures $3 \mathrm{E}-\mathrm{H}$ ).

The ability to colonize the root system is essential for rhizobacteria to be considered as growth promoters. Various methods, such as immunofluorescence, radioimmunofluorescence and use of antibiotic resistant mutants, have been used to confirm root colonization. However, these are generally complex and time-consuming methods (SILVA et al., 2003). In the present study, the agar-water test tube method proposed by Silva et al. (2003) was shown to be efficient and allowed simple and rapid visualization of the capacity of rhizobacterial isolates to colonize eucalypt seedling root systems. Furthermore, it was possible to select isolates based on the response observed in the seedlings originating from microbiolized seeds as compared to nonmicrobiolized seeds (controls). Although the effect on in vitro growth was not quantified, $42 \%$ of the 50 isolates tested exhibited root and shoot growth stimulation in E. grandis, while $18 \%$ caused necrosis and were eliminated from the selection program. In an analogous study, it was found that $40 \%$ of the 150 Pseudomonas isolates used to inoculate wheat plants stimulated growth, $40 \%$ inhibited growth and $20 \%$ presented no significant effect (LUGTENBERG et al., 1996).

In future studies root colonization should be followed in the field, since the root colonization capacity depend on environmental factors, bacterial characteristics and plant exudates, making root colonization a complex process (BENIZRI et al., 2001). Normally, rhizobacteria are applied only once to seeds. From then on, the bacterial inoculum must establish itself in the plant rhizosphere in a sufficient population to promote beneficial effects. However, for the bacteria to survive they must use plant host root nutrient exudates, proliferate and be able to efficiently colonize roots and compete with other soil microorganisms (BLOEMBERGeLUGTEMBER, 2001). It is known that the meristematic cells are the main sites of root exudation, followed by the region of root elongation. The amount of exudate varies qualitatively and quantitatively as a function of various factors, including plant species and age, soil type and fertility, light, temperature and foliar treatments. These factors can partially explain the different responses of plant host genotypes to the different rhizobacterial isolates evaluated in the present study. Furthermore, considerable quantities of exudates are released during seed germination with the region under influence known as the spermosphere (BUCHENAUER, 1998), which can favor colonization of the developing root system.

Growth promotion using rhizobacteria has been shown to be inconsistent, most likely because of the complex relationships between the bacterial strain used, the specific host plant, the soil conditions, and the root environment (VONDERWELL et al., 2001). Few studies have been published on the use of rhizobacteria to promote growth in other forest cultures. Eneback et al. (1998) observed that all isolates tested significantly increased the rate of plantlet emergence in Pinus taeda L. and P. elliottii Engelm. However, growth and dry weight results varied, with increases and decreases observed, depending on the isolate and species. Significant differences in response of different eucalypt species to different rhizobacterial isolates was observed in the present study, though no negative effect was observed on the variables analyzed.

Variations in the different Eucalyptus spp. responses to selected isolates may be related to the different mechanisms of growth promotion (TEIXEIRA et al., 2005). Although not completely clarified, it is known that rhizobacteria promote growth through their ability to produce or change the concentration of plant hormones (CATTELAN et al., 1999) and interaction between plants and bacteria depend intimately on the quantity of hormone furnished by the plant (PATTEN e GLICK, 1996). For example, inoculation wit Bacillus subtilis strain LS211 (formerly BS1) decreased shoot and root biomass and root length in the greenhouse, while inoculation with Bacillus pumilis strains INR7 increased root branching, a characteristic associated with increased auxin levels in roots (CHANWAY et al., 1991a). Host plant-dependent stimulus of rooting development of cuttings was observed in work carried out with a mutant of $P$. fluorescens that produces a high amount of indoleacetic acid (IAA) (DUBEIKOVSKY et al., 1993). This indicates that the effect of IAA depends not only on the quantity produced by the bacteria, but also on the endogenous level of the hormone in the plant, which may vary according to plant genotype and age. For

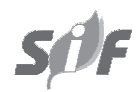

R. Árvore, Viçosa-MG, v.33, n.1, p.1-9, 2009 
PGPR to have a beneficial effect on plant growth via an enhancement of the nutrient status of their host, there obviously needs to be a intimate relationship between the PGPR and the host plant. However, the degree of intimacy between the PGPR and the host plant can vary depending on where and how the PGPR colonizes the host plant. Relationships between PGPR and their hosts can be categorized into two levels of complexity: i) rhizospheric and ii) endophytic (VESSEY, 2003).

The production of compounds with cytokinin activity is considered the main factor responsible for stimulating plant growth (BUCHENAUER, 1998). It was demonstrated that growth of Rhaphanus sativus L. (horse radish) cv. "Cherry Belle" was increased by a Pseudomonas isolate that produced compounds with cytokinin activity (SALAMONE et al., 1997). The quantity and type of transzeatine and its derivatives produced by rhizobacterial isolates has been estimated in tobacco plant tissue through immunoassays (BUCHENAUER, 1998). Another mechanism by which rhizobacteria promote plant growth is through reduction in plant ethylene level. It has been demonstrated that various soil bacteria, especially PGPR, can effectively reduce the level of ethylene by the following mechanism (GLICK et al., 1994; GLICK et al., 1995; HALL et al., 1996).

Other mechanisms of growth promotion include suppression of harmful or pathogenic microorganisms, solubilization of natural phosphates and promotion of symbiotic associations. Therefore, production of eucalypt seedlings employing specific rhizobacterial isolates presents itself as a promising technology, given the results obtained in this study.

\section{CONCLUSION}

The method used to evaluate "in vitro" root colonization was able to indicate if the effect was benefic or deleterious allowing to pre-select isolates as potential growth promoter. There was interaction among isolates of rhizobacteria and Eucalyptus species for seed germinating and seedling growth.

\section{REFERENCES}

BENIZRI, E.; BAUDOIN, E.; GUCKERT, A. Root colonization by inoculated plant growthpromoting rhizobacteria. Biocontrol Science and Technology, v.11, n.5, p.557-574, 2001.
BLOEMBERG, G. V.; LUGTENBER, B. J. J.

Molecular basis of plant growth promotion and biocontrole by rhizobacteria. Current

Opinion Plant Biology, v.4, p.343-350, 2001.

BUCHENAUER, H. Biological control of soil-borne diseases by rhizobacteria. Journal of Plant

Disease Protected, v.105, n.4, p.329-348, 1998.

CATTELAN, A. J.; HARTEL, P. G.; FUHRMANN, J. J. Screening for plant growth-promoting rhizobacteria to promote early soybean growth. Soil Science Society America Journal, v.63, p.1670-1680, 1999.

CHANWAY, C. P. Inoculation of tree roots with PGPR soil bacteria: an emerging technology for reforestation. Forest Science, v.43, n.1, p.99-112, 1997.

CHANWAY, C. P.; HOLL, F. B. First year field performance of spruce seedlings inoculated with plant growth promoting rhizobacteria.

Canadian Journal of Microbiology, v.39, n.11, p.1084-1088, 1993a.

CHANWAY, C. P.; HOLL, F. B. Ecotypic specificity of spruce emergence-stimulating Pseudomonas putida. Forest Science, v.39, n.3, p.520-527, 1993b.

CHANWAY, C. P.; HOLL, F. B. Growth of outplanted lodgepole pine seedlings one year after inoculation with growth promoting rhizobacteria. Forest Science, v.40, n.2, p.238-246, 1994.

CHANWAY, C. P.; RADLEY, R. A.; HOLL, F. B. Inoculation of conifer seed with plant growthpromoting Bacillus strains causes increased seedlings emergence and biomass. Soil Biology and Biochemistry, v.23, n..6, p.575-580, 1991a.

CHANWAY, C. P.; TURKINGTON, R.; HOLL, F. B. Ecological implications of specificity between plants and rhizosphere microorganisms. Advance Ecology Research, v.21, p.121-169, 1991b.

CUNHA, J. F. et al. Efeito "in vitro" de antibióticos e rizobactérias no controle de bactérias fitopatogênicas ao Eucalyptus spp. Revista Árvore, v.30, n.6, p.871-876, 2006. 
DUBEIKOVSKY, A. N. et al. Growth promotion of blackcurrant softwood cuttings by recombinant strain Pseudomonas fluorescens BSP53a synthesizing an increased amount of indole-3acetic-acid. Soil Biology and

Biochemistry, v.25, p.1277-1281, 1993.

ENEBAK, S. A.; WEI, G.; KLOEPPER, J. W. Effects of plant growth-promoting rhizobacteria on loblolly and slash pine seedlings. Forest Science, v.44, n.1, p.139-144, 1998.

GLICK, B. R. et al. 1-Aminocyclopropane-1carboxylic acid deaminase mutants of the plant growth promoting rhizobacterium Pseudomonas putida GR 12-2 do not stimulate canola root elongation. Canadian Journal of

Microbiology, v.40, n.11, p.911-915, 1994.

GLICK, B. R.; KARATUROVIC, D. M.; NEWELL, P. C. A novel procedure for rapid isolation of plant growth-promoting pseudomonads. Canadian Journal of Microbiology, v.41, n.6, p.533-536, 1995.

HALL, J. A. et al. Root elongation in various agronomic crops by the plant growth promoting rhizobacterium Pseudomonas putida GR 12-2. Israel Journal of Plant Science, v.44, n.1, p.37-42, 1996.

KADO, E. I.; HESKETT, M. G. Selective media for isolation of Agrobacterium, Corynebacterium, Erwinia, Pseudomonas and Xanthomonas.

Phytopathology, v.60, n.6, p.969-976, 1970.

LUGTENBERG, B. et al. Molecular basis of rhizosphere colonization by Pseudomonas bacteria. In: INTERNATIONALSYMPOSIUMONMOLECULAR PLANT-MICROBEINTERACTIONS. BIOLOGYOF PLANT-MICROBEINTERACTIONS, 8., 1996, Knoxville. Procedings... Knoxville: 1996. p.433-440.

MAFIA, R. G. et al. Crescimento de mudas e produtividade de minijardins clonais de eucalipto tratados com rizobactérias selecionadas. Revista Árvore, v.29, n.6, p.843-851, 2005.
PATTEN, C. L.; GLICK, B. R. Bacterial biosynthesis of indole-3-acetic acid. Canadian Journal of Microbiology, v.42, n.3, p.207-220, 1996.

SALAMONE, I.E.G.; NELSON, L.; BROWN, G. Plant growth promotion by Pseudomonas PGPR cytokinin producers. In: INTERNATIONAL WORKSHOP ON PLANT GROWTH-PROMOTING RHIZOBACTERIA. PLANT GROWTHPROMOTING RHIZOBACTERIA, 4., 1997, Sapporo. Present status and future prospects. Sapporo: Japan-OECD Joint Workshop, 1997. p.316-19.

SHISHIDO, M.; CHANWAY, C. P. Colonization and growth promotion of outplanted spruce seedlings pre-inoculated with plant growthpromoting rhizobacteria in the greenhouse. Canadian Journal Forest Research, v.30, p.845-854, 2000.

SILVA, H. S. A.; ROMEIRO, R. S.; MOUNTEER, A. Development of a root colonization bioassay for rapid screening of rhizobacteria for potential biocontrol agents. Journal of Phytopathology, v. 151, n.1, p.42-46, 2003.

TEIXEIRA, D. A. et al. Evidências de indução de resistência sistêmica à ferrugem do eucalipto mediada por rizobactérias promotoras do crescimento de plantas. Fitopatologia Brasileira, v.30, n.4, p.350-356, 2005.

VESSEY, J. K. Plant growth promoting rhizobacteria as biofertilizers. Plant Soil, v.255, n.2, p.571-586, 2003.

VONDERWELL, J. D.; ENEBAK, S. A.; SAMUELSON, L. J. Influence of two plant growth-promoting rhizobacteria on loblolly pine root respiration and IAA activity. Forest Science, v.47, n.2, p.197-202, 2001. 